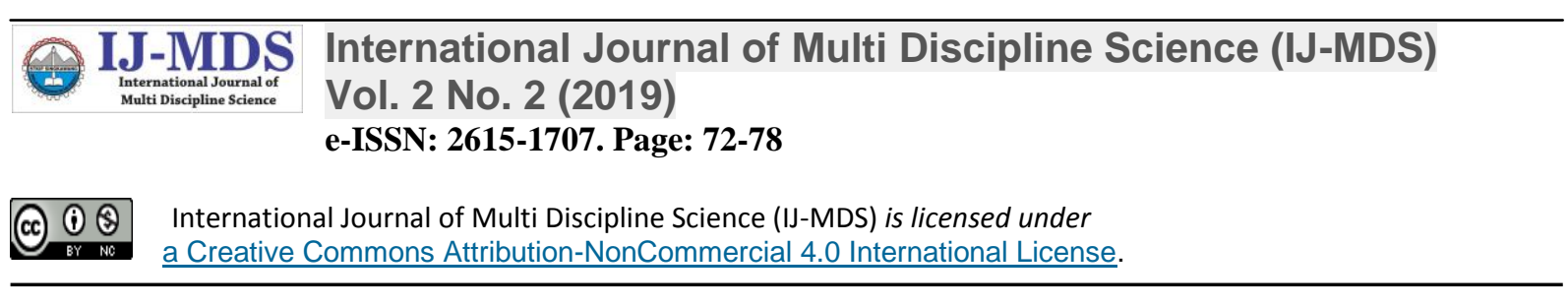

\title{
Early Warning System Technology Innovation Study in Flood Disaster Mitigation in Aren Village Area Bontang Disability
}

\author{
Nikita Adriyani ${ }^{1}$, Rio Jumardi ${ }^{2}$, Al Rosyid Anggi Satrya ${ }^{3}$, Zaini ${ }^{4,}$ *) \\ Pupuk Kalimantan Timur, Indonesia ${ }^{1,3}$, Sekolah Tinggi Teknologi Bontang, Indonesia ${ }^{2,4}$ \\ nikita.adriyani@pupukkaltim.com ${ }^{1}$, riojumardi@stitek.ac.id ${ }^{2}$, al.rosyid.a@ mail.ugm.ac.id ${ }^{3}$, \\ zaini.math@gmail.com ${ }^{4}$ \\ ${ }^{*}$ Corresponding author
}

\author{
Keywords: \\ Flood Disaster Mitigation, \\ Technology Innovation, \\ Emergency, \\ Early Warning System, \\ Aren Village
}

\begin{abstract}
AWLR with the application of I Am Aren is been CSR program of PT Pupuk Kaltim that was developed as a flood disaster mitigation in order to be able to minimize the loss of society cause of flooding. Obtaining data used black-box testing techniques, surveys, and interviews which are then analyzed inductively. Respondents involved as many as 40 people for the survey and 20 people for the interview. The research approach used qualitative research. The results showed that the blackbox testing for the recording feature was following the procedure and could provide accurate information. Respondents did not undergo problems in the using and the results of the implementation of the tool were able to reduce losses to $74.4 \%$ from the previous loss.
\end{abstract}

\section{INTRODUCTION}

PT Pupuk Kaltim as a company has CSR which is spread in Bontang City and then contributes to the building by physical (infrastructure) and non-physical (SDM development). Implementation of CSR by companies as an obligation (U.U. No. 40 Tahun 2007), relations between companies, communities, and countries (Savitz, 2006) with the aim that the growth of the prosperous of individuals, communities, society (Strotmann, Volkert, and Schmidt, 2019) around the company environment. CSR PT Pupuk Kaltim has implemented programs including better living in Malahing, Permata Bunda Business Incubator and Disabled Friendly Aren Village. Along with the vision and mission of Bontang City to manifest a smart city, green city, and creative city. So the CSR program develops appropriate technology as innovation, namely Automatic Water Level Recorder (AWLR) in the Aren Village area as a selected area. AWLR is a data recording technology with a mechanical/graphic type (Akrom \& Agustiani, 2018).

The Disabled Friendly Aren Village was declared on August 18, 2018, and got a village decision letter in early 2019 initiated by awareness to grow and organize its area. Geographically, the map of Kampung Aren can be observed in Fig 1.

The raising up of social movements can be initiated by the signing of an online petition by societies that have the same goal (Golhasani \& Hosseinirad, 2016). But the societies in Kampung Aren use more the principle of volunteerism collectively without any petitions. Collective behavior as a form of approach by giving much greater attention to the importance of organizational role factors in social 


\section{IJ-MDS International Journal of Multi Discipline Science (IJ-MDS) \\ Vol. 2 No. 2 (2019) \\ e-ISSN: 2615-1707. Page: 72-78}

movements, which they call the resource mobilization theory (McCharty and Zald, 1977). The purpose of this social movement to create ideal conditions for a prosperous society economically, socially, and environmentally.

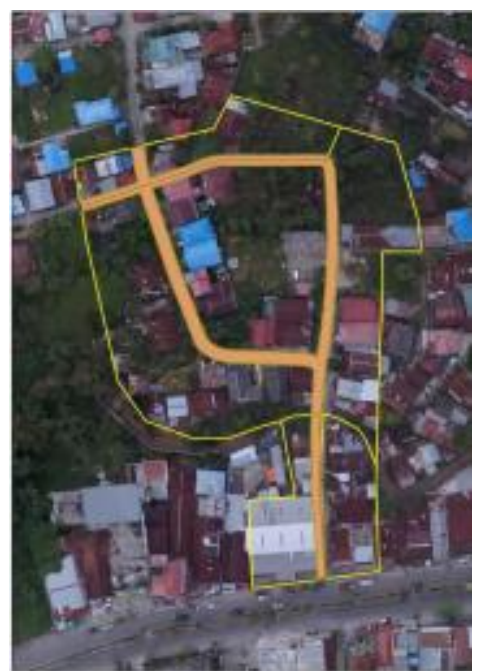

Fig 1. Map of Aren Village

Aren village is an area located in a watershed area (DAS) and it is known that affected by floods which paralyzed all societies' activities and caused enough high losses. Flood conditions in Aren Village can be observed according to Fig 2.
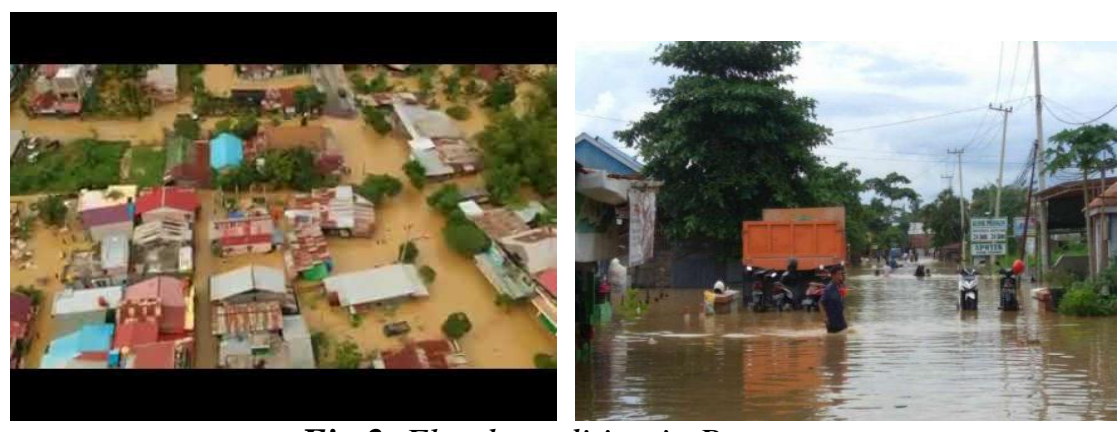

Fig 2. Flood condition in Bontang

AWLR development in Aren Village is based on 10 considerations in between 10 gold points which include (1) Gate Entrance, (2) Bridge Spot, (3) Aren Farm (Interaction Center), (4) Nursery and Composter Area, (5) Emergency \& Early Warning System, (6) Disability Friendly Mosque, (7) Main Road Spot, (8) Citizen Integrated Business, (9) Infiltration Wells, and (10) Inbis Permata Bunda as the empowerment of children with special needs.

The installation of AWLR on the river in Aren Village expected that it can be created early warning system (EWS) that can be accessed by the societies regarding the status of river water conditions (emergency) in real-time. EWS is implemented as a chain of information communication systems consisting of a collection of sensors, event detection, and decision sub-systems. These systems work together to predict signal disturbances that can adversely affect the stability of the system. Except that, these systems provide time tolerance for the response of the surrounding system in preparing needs and minimizing the side effects of the disaster (Waidyanatha, 2010). The AWLR studying in realizing EWS is needed to know in depth its usefulness for the mitigation of Flood disasters in Aren Village and at the same time to filter the response of the societies in Aren Village to the installation of AWLR with I am Aren Application. 


\title{
METHOD
}

This studying seeks to describe the results of a study of technological innovation early warning systems in flood disaster mitigation. Therefore, the research approach was used that a qualitative research approach. The qualitative research method is a method used to answer research problems related to data in the form of narratives that originate from interviews, observations, document extraction (Wahidmurni, 2017). Techniques were used in collecting research data include black-box testing techniques about water level records, survey techniques (loss impact), and interview techniques (easy of use of the application). Black-box testing is a test that only focuses on the output generated for an input given to the system and execution conditions (Williams, 2010). In the case of water level elevation information, the system was designed to provide real-time recording with a count time duration of 30 seconds. Respondents involved from Aren Village were 40 people for survey data, and 20 people for interviews that included the impact of installing Automatic Water Level Recorder in flood disaster mitigation. The draft calculation of the high water level can be observed in Fig 3.

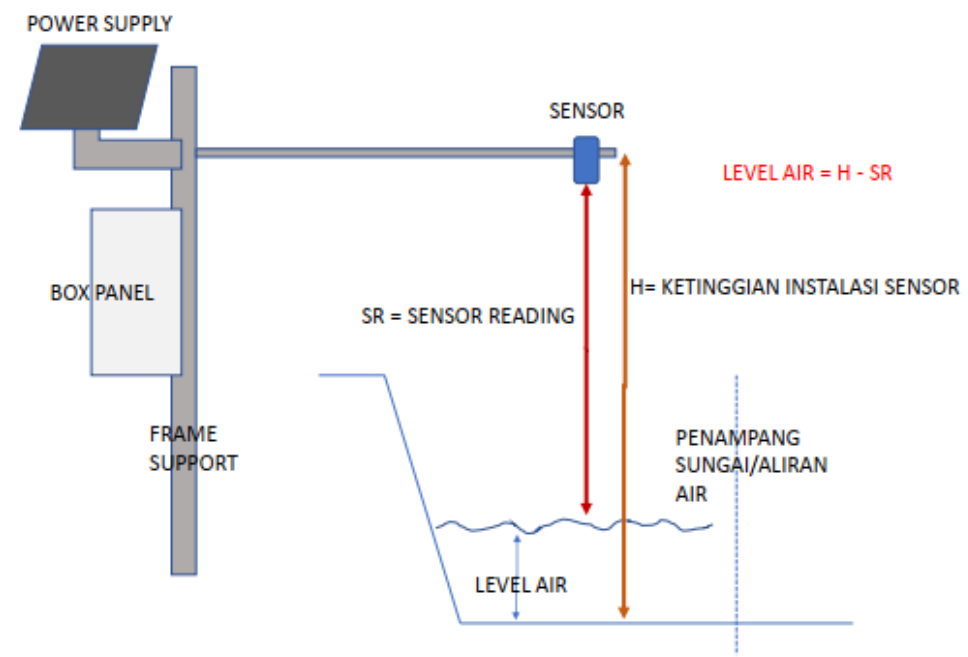

Fig 3. Design calculation of water high level

All data obtained were then analyzed inductively with three stages, namely data reduction, data presentation, and verification.

\section{RESULTS AND DISCUSSIONS}

\begin{abstract}
AWLR and I Am Aren
AWLR as a tool to measure the height of a developing water level on the basis to minimize conventional measurement fatigue. In conventional measurements, the water level is observed by looking at the water level threshold directly (Akrom \& Agustiani, 2018). The results of these measurements have an impact on the occurrence of potential large recording and measurement errors. The results of designing tools in a study based on black-box testing show that all features for the application are not interrupted. This can be observed in the measurement and recording of the water level currently running through the transmission of data from the measurement location to the data storage location in real-time. The developed system contains four important parts, namely sensor, controller, data uploader, and power supply. Each of the four parts consists of hardware and software programmed in order suitable for specifications that need. For the data presentation side, the device was developed based on IoT (internet of things), where the data readings from reading will be sent to a database by online which it will be processed to be presented to the societies in the form of information that can be accessed on the website. The development of an IoT-based system in the tool is intended to deliver information faster. Some uses of IoT include IoT in Smart Hotels (Amer \& Alqhtani, 2019), IoT for Education (Lacrama, 2019), Data Analysis Models on Computing Networks
\end{abstract}




\section{IJ-MIDS International Journal of Multi Discipline Science (IJ-MDS) \\ Vol. 2 No. 2 (2019) \\ e-ISSN: 2615-1707. Page: 72-78}

(Jan \& Bevinakoppa, 2019), and others. The AWLR architecture design and equipment used can be observed in Fig 4 and Fig 5.

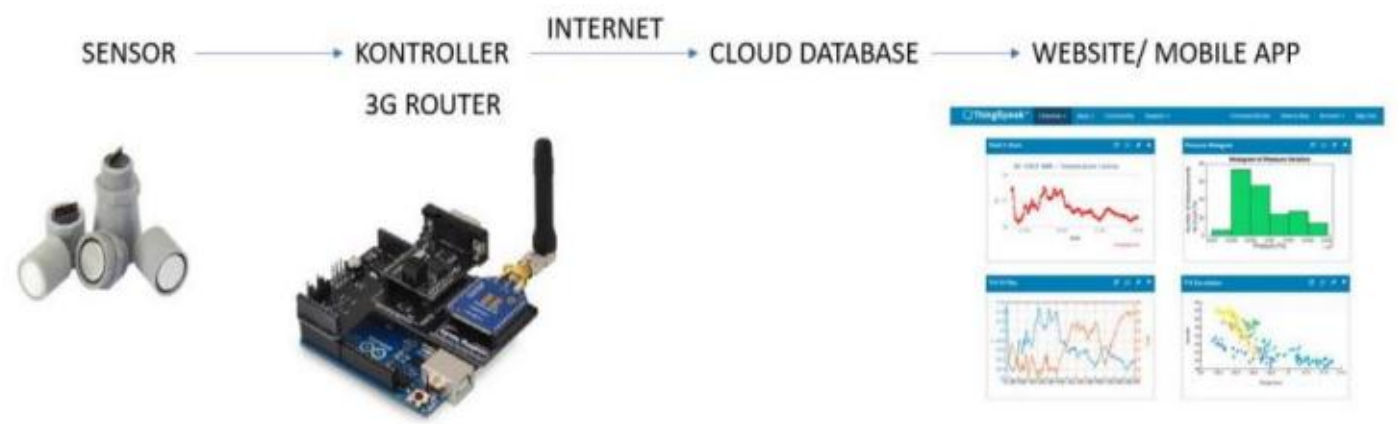

Fig 4. The system architecture of AWLR
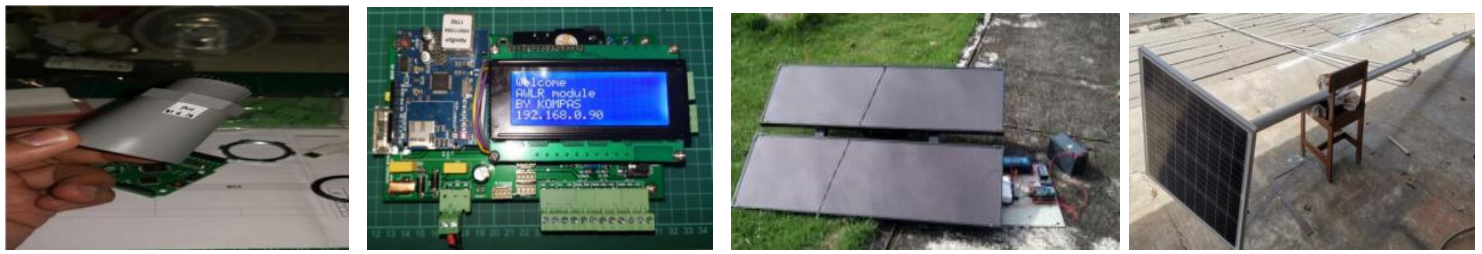

Fig 5. Tolls are used

Tools will be installed at several points of river flow in Bontang city so that the availability of information will be interconnected between upstream to the river mouth. The placement of these tools can be observed in Fig 6. The working procedure of this tool is like the concept of a remote sensing system image. The concept of river water level measurement with the AWLR system is carried out by using an ultrasonic-based sensor (sonar) that detects the surface of the object, the performance of the sensor emits sound waves that will be reflected by the surface of the object and then the controller will be calculated the time of linear reflection by calculating the distance obtained. Then it is processed in the controller to get the water high-level results, then the data will be sent to an online database using the MQTT protocol with REST API in the form of JSON, then the data will be processed and integrated into the mobile app is developed.
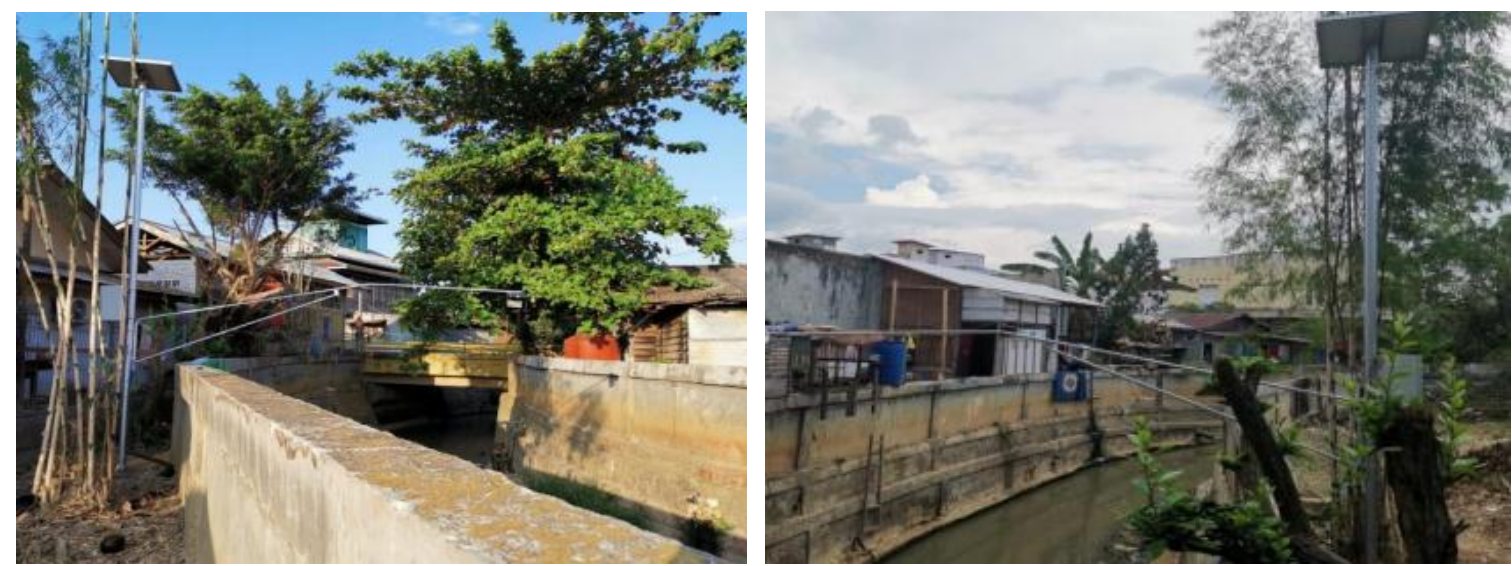

Fig 6. Tolls are installed in Aren village

I Am-Aren is the "Integrated Application Models for Aren Village" which was developed by the Deep dive project through the Permata Bunda Business Incubator with full support from the CSR Department of PT Pupuk Kaltim which is intended for societies of the Disabled Friendly Aren Village. By carrying out the concept of integration, I Am Aren wants to grow and become an appropriate 


\section{IJ-MDS International Journal of Multi Discipline Science (IJ-MDS) \\ Vol. 2 No. 2 (2019) \\ e-ISSN: 2615-1707. Page: 72-78}

versatile platform to help the process of digitizing development in Aren Village. This application can be downloaded at the link bit.ly/Iam-Aren and a storage capacity of 12 Megabytes. Users of this application require registration.

How it works in the early warning system feature in the application I Am Aren is very practical and has a simple and interactive display. AWLR sends water high-level data to a thing speak server (cloud system). taking of water high-level data in the application through a server is every 30 seconds. Then, the data received is converted into an algorithm to inform the status of Safe/Alert/Danger status by calculating the water high level with the height of the ditch/river. Schematic results of tests in applications regarding calculations between water level, history, and status can be observed as in Fig 7, Fig 8, and Fig 9.
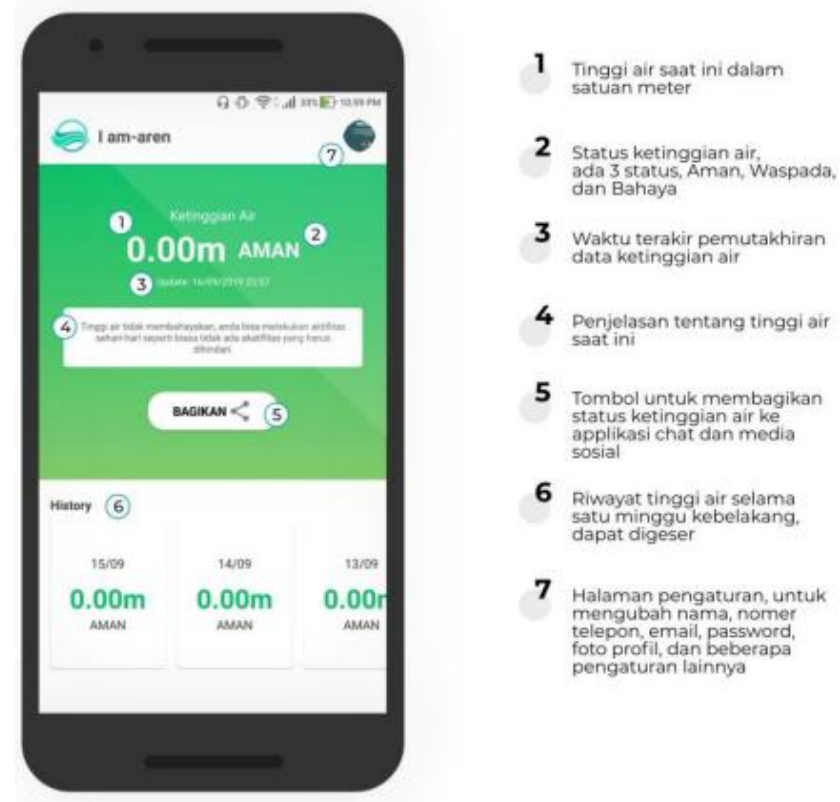

Fig 7. Initial display of I am Aren application

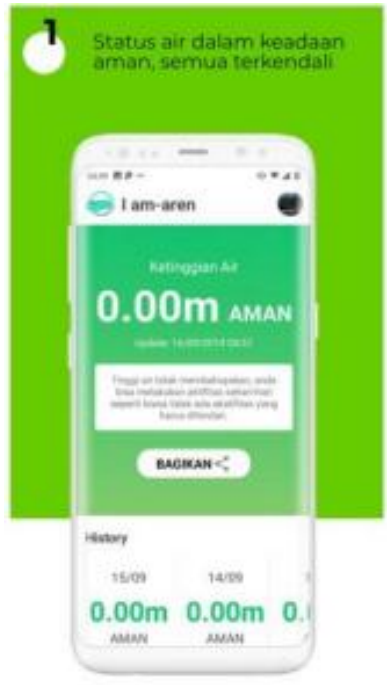

AMAN

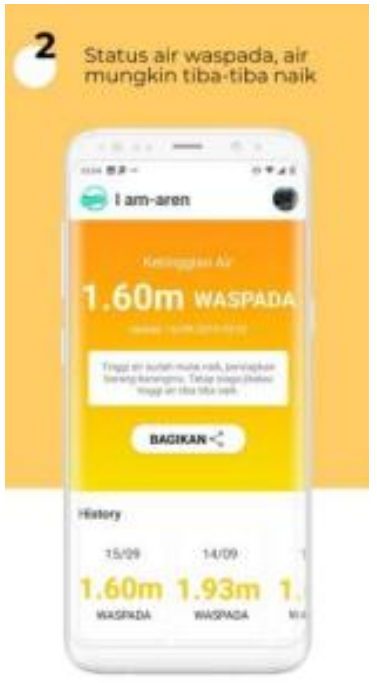

WASPADA

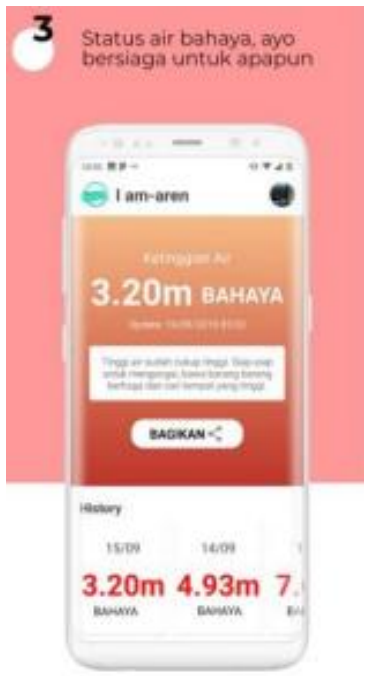

BAHAYA

Fig 8. Three conditions of water statues in I Am Aren application 


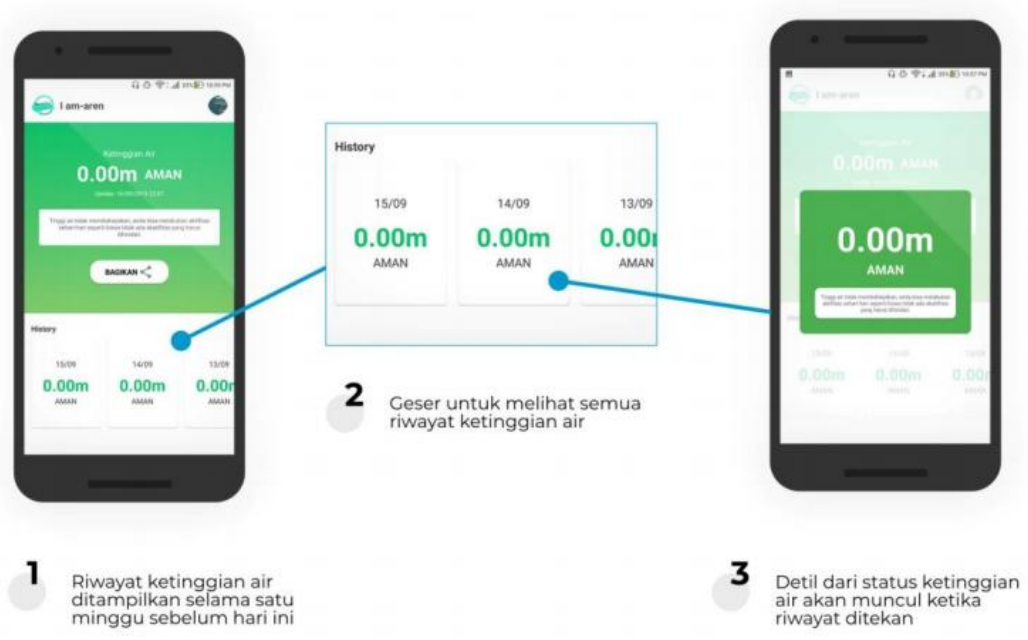

Fig 9. Recall water high level

Green means safe, yellow means alert while red means danger. Besides displaying colors, the application display shows the height of the water. Notifications and notice will still appear even if societies are not currently opening the I Am Aren application.

\section{Respond of Aren Village societies}

Collecting data on the response of the societies of Aren village (questionnaire and interview) was carried out after the installation and socialization activities. The purpose of these activities is to bring the application closer to the community so that they know using the application. The results of the data analysis showed savings from losses caused by floods after monitoring by the societies reached Rp 303.6 million. Meanwhile, society's losses caused flood before the installation of AWLR reached an estimated 408.3 million and most were household furniture, electronics, and precious letter. The results of interviews with respondents who use the application show that respondents can install the application without any constraints, its use is very practical and the water level information is constantly updated. This indicates that this application can be utilized by societies as a form of flood disaster response. Besides that, the societies continue to increase their awareness of the importance of environmental cleanliness and good waste management, namely not to throw garbage in the river.

\section{CONCLUSION AND SUGGESTION}

I Am Aren application that had been implemented to the societies of Aren village can provide information about water high level as a form of flood disaster mitigation. Black-box testing on each application feature in a successful condition without problems that interfere with the system. Survey and interview results showed that the community can reduce losses up to $74.4 \%$ due to flooding and the use of applications is felt to be very easy as other applications. However, the design of the tool currently has shortcomings including (1) it is still limited to the use of the Android platform, and (2) it requires a data connection to the server to transfer data in real-time.

\section{REFERENCES}

Akrom, F. I., Agustiani, H. (2018). Evaluasi Kinerja Alat Ukur Tinggi Muka Air Otomatis Menggunakan Kalibrator Di Laboratorium. Jurnal Teknik Hidraulik, 9(2), 127-138.

Amer, M. \& Alqhtani, A. (2019). IoT Applications in Smart Hotel. International Journal of Internet of Things and Web Service, 4, 8-13.

Golhasani, Akbar., Hosseinirad, A. (2016). The Role of Resource Mobilization Theory in Social Movement. International Journal of Multicultural and Multiregilious Understanding, 3(6), 2 14. 


\section{IJ-IMDS International Journal of Multi Discipline Science (IJ-MDS)}

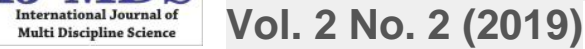

e-ISSN: 2615-1707. Page: 72-78

Ian, T. \& Bevinakoppa, S. (2019). Distributed Data Analytic Models for IoT Edge Computing Network. International Journal of Internet of Things and Web Service, 4, 67-71.

Lacrama, L \& Alexa, F. (2019). Internet of Things \& Augmented Reality App for Education. International Journal of Internet of Things and Web Service, 4, 19-26.

McCharty, J. D. \& Zald, M. N. (1977). Resource Mobilization and Social Movements: A Partial Theory. American Journal of Sociology, 82(6), 1217-1218.

Savitz, Andrew, W. (2006). The Triple Bottom Line. New Jersey: John Wiley \& Son.Inc.

Strotmann, H., Volkert, J., \& Schmidt, M. (2019). Multinational Companies: Can They Foster WellBeing in the Eyes of the Poor? Results from an empirical case study. International Journal of Corporate Social Responsibility, 4(2), 2-14.

Undang-Undang Nomor 40 Tahun 2007 Tentang Perseroan Terbatas.

Wahidmurni (2017). Pemaparan Metode Penelitian Kualitatif. (online) http://repository.uinmalang.ac.id/1984/2/1984.pdf

Waidyanatha, N. (2010). Towards a typology of integrated functional early warning systems. International Journal of Critical Infrastructures, 6(1), 31-51.

Williams, L. (2010). A(Partial) Introduction to Software Engineering Practices and Methods. North Carolina: Nort Carolina State University. 